\title{
ANALISIS KEBERADAAN DAN PENYEBAB TERJADINYA TEKANAN LUAP BERDASARKAN EMPAT DATA SUMUR EKSPLORASI DI DAERAH LEPAS PANTAI JAWA TIMUR
}

\author{
CHARLIANTO VALDO \\ Program Studi Teknik Geologi, Fakultas Ilmu dan Teknologi Kebumian, Institut Teknologi \\ Bandung (ITB), Jl. Ganesha No.10, Bandung, Jawa Barat, Indonesia, 40132, Email: \\ valdo.pardosi@gmail.com
}

\begin{abstract}
Sari-Cekungan Jawa Timur merupakan salah satu cekungan sedimen dengan kegiatan eksplorasi minyak dan gas (migas) yang cukup intesif. Salah satu permasalahan yang banyak ditemukan di cekungan ini adalah keberadaan tekanan luap di sumur pengeboran. Penelitian ini dilakukan pada empat sumur lepas pantai Jawa Timur. Deteksi keberadaan tekanan luap di daerah penelitian diketahui dengan menganalisis data log tali kawat, geokimia batuan induk, laporan kegiatan pengeboran, dan data tekanan sumur. Analisis penyebab terjadinya tekanan luap pada daerah penelitian dilakukan berdasarkan data kematangan batuan induk, data log tali kawat, dan plot Dutta. Hasil analisis menunjukkan bahwa satu sumur berada pada kondisi hidrostatik, sedangkan tiga sumur lainnya berada pada kondisi tekanan luap. Tekanan luap pada satu sumur disebabkan oleh batuan yang gagal kompak, sedangkan dua sumur lainnya disebabkan juga oleh kematangan batuan induk dan diagenesis mineral lempung. Metoda Eaton digunakan untuk membuat estimasi tekanan pori di sumur. Angka eksponen Eaton untuk log sonik pada daerah penelitian berkisar antara 1,1-2,6. Perbedaan kedalaman puncak tekanan luap dipengaruhi oleh kecepatan sedimentasi dan variasi litologi.
\end{abstract}

Kata kunci: tekanan luap, tekanan pori, ketidakseimbangan kompaksi batuan, kematangan hidrokarbon, diagenesis mineral lempung.

\begin{abstract}
The East Java Basin is one of the sedimentary basins with a fairly intensive oil and gas exploration activities. One of the most common problems in this basin is the overpressure occurence in the drilling well. The study was conducted in four wells located in the East Java offshore. The presence of overpressure in the study area is known by analyzing wireline log, source rock geochemical data, drilling report, and well pressure data. The analysis of overpressure generating mechanism in the study area is conducted based on source rock geochemical data, wireline log, and Dutta plot. The result of the analysis shows that one well is in hydrostatic condition while three other wells are in overpressure condition. The overpressure in one well is caused by disequilibrium compaction (loading mechanism), while the other wells are also caused by source rock maturation and clay diagenesis (nonloading mechanism). The Eaton Method is used to estimate pore pressure in overpressured wells. The Eaton exponent number in the study area ranges from $1.1-2.6$ for sonic log. The difference of top overpressure is influenced by sedimentation rate and lithologic variation.
\end{abstract}

Keywords: overpressure, pore pressure, disequilibrium compaction, hydrocarbon maturation, clay diagenesis.

\section{PENDAHULUAN}

\subsection{Latar belakang}

Pengetahuan mengenai kondisi bawah permukaan suatu daerah merupakan hal yang sangat penting dalam melakukan eksplorasi minyak dan gas bumi. Salah satu kondisi tersebut adalah tekanan pori. Pengetahuan mengenai tekanan pori ini sangat membantu dalam melakukan desain pengeboran, untuk menghindari risiko pengeboran dan mendapatkan waktu yang efektif selama melakukan pengeboran.
Tekanan pori dengan nilai yang lebih besar dari tekanan hidrostatis normal disebut sebagai tekanan luap. Tekanan luap ini dapat menyebabkan masalah dalam melakukan pengeboran seperti kick dan blow out. Tekanan luap dapat menyebabkan bencana seperti yang terjadi di Sidoarjo pada tahun 2006 yang menenggelamkan 11.241 bangunan dan menimbulkan kerugian lebih dari 2,7 milyar dolar (Tingay, 2015). 
Keberadaan tekanan luap di Cekungan Jawa Timur telah banyak diteliti. Manik dan Soedaljo (1984) menemukan bahwa tekanan luap berada pada kedalaman 6.000 kaki pada salah satu sumur di Cekungan Jawa Timur. Heller dkk. (2015) menyatakan bahwa Cekungan Jawa Timur merupakan merupakan salah satu cekungan di Asia Tenggara yang memiliki profil tekanan pori yang tidak biasa.

Penelitian ini bertujuan untuk mendeteksi tekanan keberadaan tekanan luap, menentukan penyebab terjadinya, dan membuat estimasi tekanan pori pada empat sumur yang berlokasi di lepas pantai Jawa Timur (Gambar 1).

\subsection{Stratigrafi daerah penelitian}

Dari hasil analisis dari empat sumur di daerah penelitian, paling tidak dijumpai tujuh formasi batuan. Penamaan formasi batuan lokasi penelitian dilakukan berdasarkan dengan kolom stratigrafi regional pada Gambar 2.

Batuan dasar hanya ditembus oleh Sumur ITB-3 pada daerah penelitian. Batuan dasar di daerah penelitian ini berupa batuan metasedimen.

Setelah batuan dasar, terdapat Formasi Ngimbang. Di Sumur ITB-2, Formasi Ngimbang berupa batupasir, batulempung, dan batugamping pada bagian atasnya. Sedangkan pada Sumur ITB-3, Formasi Ngimbang ini berupa batugamping.

Formasi Prupuh diendapkan setelah Formasi Ngimbang. Formasi Prupuh ini berupa batugamping yang cukup tebal pada Sumur ITB-2 dan menipis pada Sumur ITB-3. Di Sumur ITB-3 ini, Formasi Prupuh lebih banyak berkembang sebagai endapan yang halus. Pada Sumur ITB-1 yang terletak paling selatan di daerah penelitian, batugamping ini dinamakan Formasi Kujung.

Pascapengendapan batugamping Formasi Prupuh dan Formasi Kujung, lingkungan pengendapan daerah penelitian berupa laut dalam. Hal ini dicirikan oleh litologi berupa batulempung dengan sisipan batupasir dan batugamping Formasi Tawun dan batulempung Formasi Wonocolo. Selain itu, lingkungan berupa laut dalam ini juga dikonfirmasi dari hasil analisis biostratigrafi pada Sumur ITB-3 yang menunjukkan tingginya rasio fosil plangtonik terhadap bentonik yang mencapai 90:10 hingga 95:5.

Litologi yang diendapkan selanjutnya adalah batugamping Formasi Paciran. Formasi ini dijumpai pada Sumur ITB-2, ITB-3, dan ITB-4. Pada Sumur ITB-2, batugamping Formasi Paciran ini masih banyak dijumpai sisipan batulempung, sedangkan pada Sumur ITB-3 dan Sumur ITB-4 batugamping diendapkan relatif lebih masif.

Formasi Lidah merupakan formasi yang paling muda pada daerah penelitian. Litologi yang diendapkan berupa batulempung yang cukup tebal dengan sisipan batupasir dan batugamping.

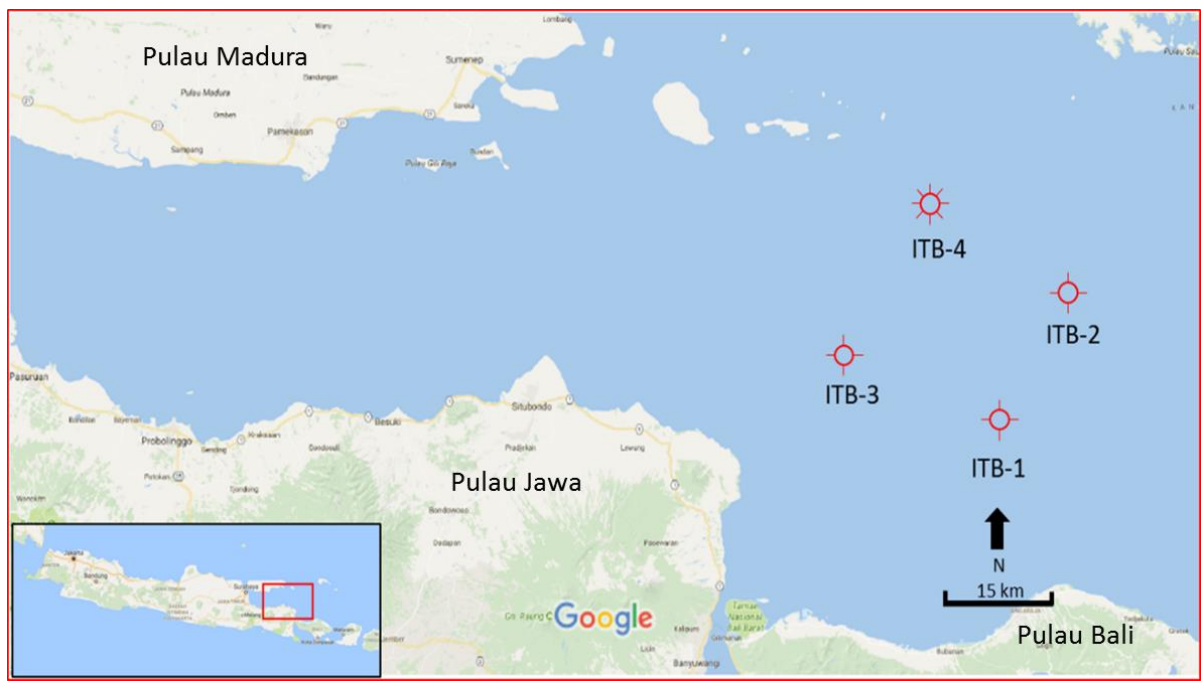

Gambar 1. Lokasi penelitian (Google maps, diakses pada November 2017). 


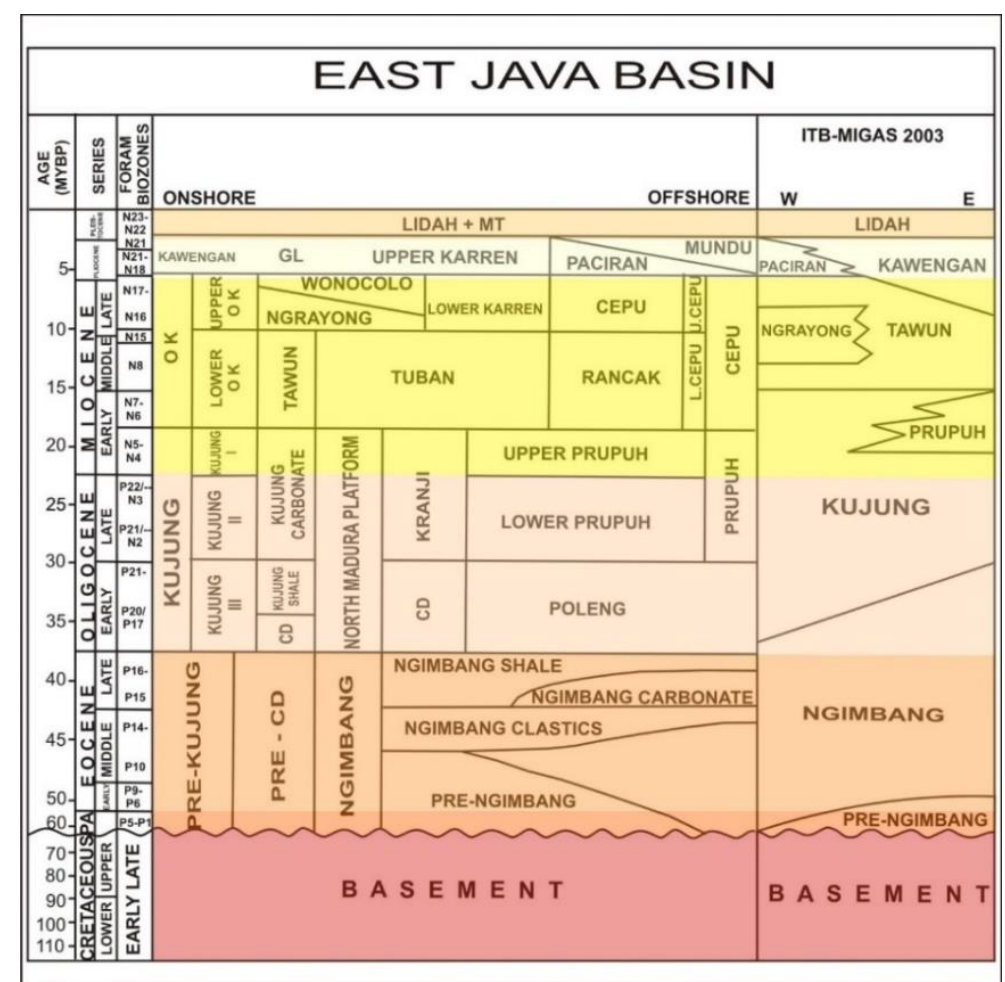

Gambar 2. Stratigrafi regional Cekungan Jawa Timur (BP Migas dan LAPI ITB, 2008).

\section{DATA DAN METODOLOGI \\ 2.1 Data}

Data yang digunakan dalam penelitian ini berupa data dari empat sumur pengeboran. Data sumur tersebut terdiri dari data log tali kawat, data log lumpur, data tekanan langsung dan tidak langsung, laporan kegiatan pengeboran, laporan geokimia, dan laporan biostratigrafi.

\subsection{Metodologi}

Untuk menentukan keberadaan tekanan luap pada tiap sumur, metode yang digunakan adalah dengan menganalisis data tekanan, baik data tekanan langsung maupun data tekanan tidak langsung. Analisis data log tali kawat dilakukan dengan melihat respon log tali kawat seiring dengan bertambahnya kedalaman. Dengan melihat perubahan respon log terhadap kedalaman, dapat diketahui keberadaan tekanan luap, puncak tekanan luap, dan secara umum penyebab terjadinya (Ramdhan dan Goulty, 2011). Analisis tersebut kemudian diintegrasikan dengan kegiatan pengeboran yang berkaitan dengan tekanan sehingga keberadaan tekanan luap dan puncak kedalamannnya dapat diketahui dengan lebih baik.
Penentuan penyebab terjadinya tekanan luap dilakukan berdasarkan analisis data geokimia batuan induk. Untuk sumur yang tidak memiliki data kematangan batuan induk, dilakukan pemodelan kematangan batuan induk untuk mengetahui apakah batuan induk telah matang atau tidak. Pada batuan induk yang telah matang, material solid berubah menjadi fluida yang secara otomatis meningkatkan nilai tekanan pori sehingga terjadi tekanan luap (Swarbrick dan Osborne, 1998).

Selain berdasarkan kematangan batuan induk, penentuan penyebab terjadinya tekanan luap dilakukan dengan mendeteksi adanya diagenesis mineral lempung dari smektit menjadi ilit. Diagenesis mineral lempung smektit menjadi ilit mengakibatkan perubahan sebagian massa padat batuan menjadi fluida sehingga terjadi tekanan luap (Swarbrick dan Osborne, 1998). Metode untuk mengetahui diagenesis mineral lempung dari data log tali kawat dikemukakan oleh Dutta (2002). Dutta melakukan plot silang log sonik terhadap densitas dari data sumur yang berlokasi di Gulf Coast yang telah dianalisis tingkat diagenesisnya. Dari plot silang ini, didapatkan garis eodiagenesis yang merupakan garis kompaksi untuk smektit dan garis telodiagenesis yang merupakan garis kompaksi untuk ilit. Pada 
plot Dutta, ketika terjadi perubahan persebaran data dari garis kompaksi smektit menjadi garis kompaksi ilit seiring dengan bertambahnya kedalaman dapat disimpulkan bahwa telah terjadi diagenesis mineral lempung dari smektit menjadi ilit.

Estimasi tekanan pori juga dilakukan dengan berdasarkan Metoda Eaton (1975) dengan menggunakan log sonik. Estimasi tekanan pori Metoda Eaton diawali dengan membuat kurva porositas normal yang disebut juga sebagai tren kompaksi normal. Tren kompaksi normal dibutuhkan kemudian dipakai untuk menentukan seberapa besar penyimpangan log tali kawat dari tren kompaksi normal. Setelah didapat nilai tren kompaksi normal, nilai tekanan pori dapat diestimasi menggunakan persamaan:

$$
P=\sigma v-(\sigma v-P n)\left(\frac{\Delta t_{n}}{\Delta t}\right)^{3}
$$

dengan $P$ : tekanan pori, $\sigma v$ : tegasan vertikal, $P n$ : tekanan hidrostatis, $\Delta t n$ : nilai sonik kompaksi normal, $\Delta t$ : nilai sonik dari pembacaan $\log$ sonik.

\section{HASIL ANALISIS}

\subsection{Analisis keberadaan tekanan luap}

Analisis dilakukan pada semua data yang sudah dikonversi ke data tegasan dan tekanan, seperti tegasan vertikal, tekanan hidrostatis, berat lumpur, pengukuran tekanan langsung, dan informasi kejadian pengeboran yang dapat mengindikasikan kondisi tekanan sumur. Data tekanan ini diintegrasikan dengan pola log tali kawat.

\subsubsection{ITB-1}

Sumur ITB-1 memiliki tiga data pengukuran langsung berupa data Formation Integrity Test (FIT) dan Leak Off Test (LOT). Pada kedalaman 4.507 kaki di bawah permukaan laut, dilakukan pengukuran FIT dengan nilai 10,14 ppg. Sementara itu, pada kedalaman 5.000 kaki di bawah permukaan laut dilakukan pengukuran FIT dan LOT dengan nilai masing-masing sebesar 10,5 dan $12 \mathrm{ppg}$. Data tekanan tidak langsung pada sumur ini berupa data berat lumpur pengeboran (Gambar 3). Berat lumpur pengeboran yang digunakan sebesar 9,2-9,5 ppg. Besar berat lumpur pengeboran ini relatif mendekati nilai tekanan hidrostatis normal.
Berdasarkan penggunaan berat lumpur pengeboran, tidak dijumpai adanya keberadaan zona tekanan luap pada sumur ini. Pola log sonik pada sumur ini masih memperlihatkan pola kompaksi normal sehingga dapat mengonfirmasi bahwa sumur ini tidak ditemukan tekanan luap, paling tidak hingga kedalaman 6.400 kaki.

\subsubsection{Sumur ITB-2}

Sumur ini memiliki data pengukuran langsung yaitu FIT dan LOT. Pengukuran FIT dilakukan pada kedalaman 4.420 kaki di bawah muka laut pada Formasi Lidah menghasilkan nilai tekanan sebesar 12,5 ppg. Pengukuran LOT dilakukan pada kedalaman 7.245, 7.567, dan 9.398 kaki di bawah permukaan laut menghasilkan nilai tekanan masing-masing sebesar 13,8 ppg, 14,6 ppg, dan 15,3 ppg (Gambar 4). Ketiga pengukuran LOT ini dilakukan pada Formasi Wonocolo. Peningkatan berat lumpur secara signifikan terjadi ketika pengeboran memasuki Formasi Lidah. Berat lumpur yang digunakan pada awal formasi ini adalah 11-11,4 ppg pada kedalaman 4.900 kaki di bawah permukaan laut. Jika dibandingkan dengan tekanan hidrostatis normal, berat lumpur yang digunakan ini lebih besar. Hal ini menandakan kedalaman ini telah berada pada zona tekanan luap.

\subsubsection{Sumur ITB-3}

Data pengukuran langsung pada Sumur ITB-3 berupa pengukuran LOT. Pengukuran LOT dilakukan pada kedalaman 2.995 kaki, 4.763 kaki, dan 8.334 kaki di bawah permukaan laut dengan nilai masing-masing tekanan sebesar 12,3 ppg, 13,5 ppg, dan 16,5 ppg. Selain dijumpai connection gas, kendala selama pengeboran sumur ini berupa hilangnya sirkulasi lumpur dan adanya overpull. Hilangnya sirkulasi lumpur dijumpai pada kedalaman 4.897 kaki. Hilangnya sirkulasi lumpur dapat disebabkan oleh terlalu besarnya tekanan lumpur yang digunakan sehingga tekanan lumpur merusak formasi batuan. Selain itu, hal ini dapat disebabkan karena zona ini berada pada lapisan batuan yang permeabel. Berdasarkan data LOT pada kedalaman 4.763 kaki, tekanan dari berat lumpur memang sangat dekat dengan nilai tekanan LOT, yaitu 3.343 psi. Overpull terjadi pada kedalaman 5.013, 5.897, 6.013, 6.728, dan 10.017 kaki di bawah permukaan laut. Pada kedalaman 5.620 kaki, 
berat lumpur yang digunakan sebesar 14 ppg. Berat lumpur pada kedalaman ini mengindikasikan bahwa pada kedalaman tersebut telah berada pada kondisi tekanan luap. Selanjutnya, berat lumpur yang digunakan relatif meningkat hingga 15 ppg hingga kedalaman 9.500 kaki, kemudian mengecil mendekati tekanan hidrostatis ketika memasuki Formasi Ngimbang dan batuan dasar (Gambar 5). Pola log sonik mulai mengalami pembalikan pada kedalaman 5.000 kaki, menandakan puncak kedalaman tekanan luap berada pada kedalaman tersebut.

\subsubsection{Sumur ITB-4}

Pengukuran tekanan langsung pada sumur ITB4 didapat dari LOT dan uji kandung lapisan. Pengukuran LOT dilakukan pada kedalaman $1.214,2.919,3.874$, dan 4.564 kaki di bawah permukaan laut menghasilkan nilai tekanan masing-masing sebesar 12,8 ppg, 14 ppg, 16,6 ppg, dan 17 ppg. Nilai tekanan formasi berdasarkan uji kandung lapisan pada kedalaman 3.993 kaki adalah 3.173 psi dan pada kedalaman 4.039 kaki sebesar 3.229 psi. Berat lumpur yang masih mencerminkan tekanan hidrostatis normal digunakan hingga kedalaman 1.160 kaki di bawah permukaan laut. Berat lumpur mulai dinaikkan menjadi 10,5 ppg pada kedalaman 1.986 kaki di bawah permukaan laut yang ekivalen dengan tekanan

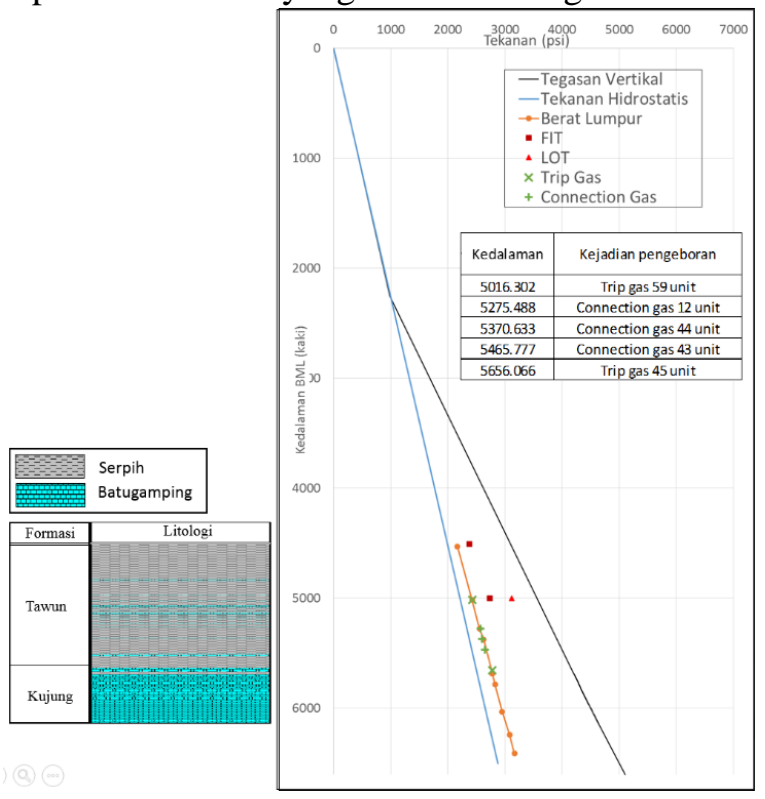

Gambar 3. Profil korelasi antara litologi, tekanan dan kedalaman pada Sumur ITB-1. sebesar 1.084 psi. Peningkatan berat lumpur secara signifikan dimulai pada kedalaman 3.500 kaki di bawah permukaan laut. Lumpur seberat 13,3 ppg digunakan pada kedalaman ini. Kemudian dinaikkan kembali menjadi sebesar 15,7-15,9 ppg pada kedalaman 3.920 hingga 4.600 kaki di bawah permukaan laut. Nilai tekanan dengan penggunaan berat lumpur sebesar ini menyatakan bahwa pengeboran telah masuk dalam zona tekanan luap.

Berat lumpur yang masih mencerminkan tekanan hidrostatis normal digunakan hingga kedalaman 1.160 kaki di bawah permukaan laut. Berat lumpur mulai dinaikkan menjadi 10,5 ppg pada kedalaman 1.986 kaki di bawah permukaan laut yang ekivalen dengan tekanan sebesar 1.084 psi. Peningkatan berat lumpur secara signifikan dimulai pada kedalaman 3.500 kaki di bawah permukaan laut. Lumpur seberat 13,3 ppg digunakan pada kedalaman ini dan kemudian dinaikkan kembali menjadi sebesar 15,7-15,9 ppg pada kedalaman 3.920 hingga 4.600 kaki di bawah permukaan laut. Nilai tekanan dengan penggunaan lumpur sebesar ini telah berada pada kondisi tekanan luap. Pembalikan pola log sonik yang dapat mengindikasikan puncak kedalaman tekanan luap pada sumur ini terlihat dengan jelas berada pada kedalaman 1.600 kaki. Profil tekanan dan kejadian pengeboran Sumur ITB-4 ditunjukkan pada Gambar 6.

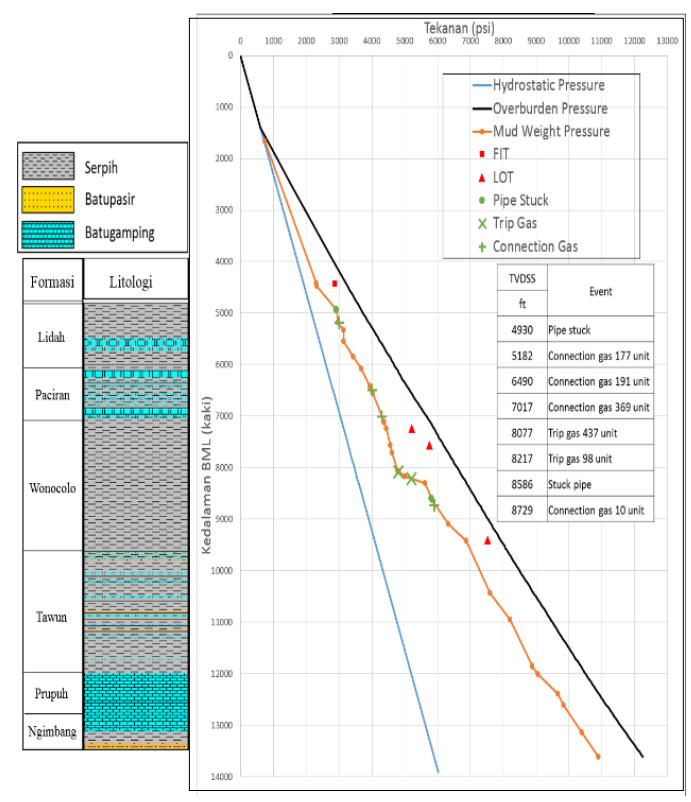

Gambar 4. Profil korelasi antara litologi, tekanan dan kedalaman pada Sumur ITB-2. 


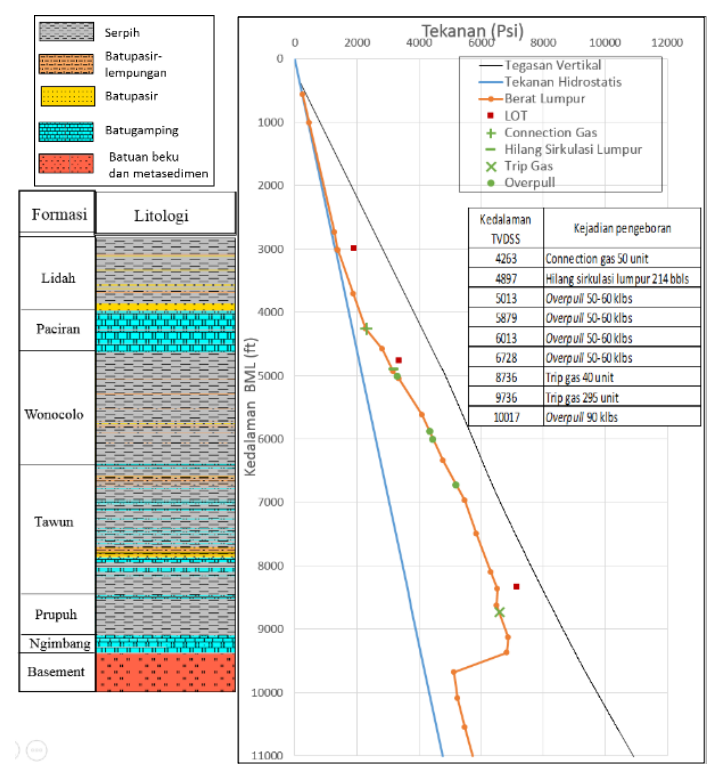

Gambar 5. Profil korelasi antara litologi, tekanan dan kedalaman pada Sumur ITB-3.

\subsection{Penyebab terjadinya tekanan luap} 3.2.1 Sumur ITB-2

Untuk mengetahui penyebab terjadinya tekanan luap pada sumur ini, dilakukan plot silang antara log densitas dengan log sonik per interval kedalaman (Gambar 7). Plot silang ini kemudian disandingkan dengan garis diagenesis mineral lempung plot Dutta. Plot silang dilakukan mulai dari kedalaman 7.200 sampai kedalaman 11.852 kaki di bawah permukaan laut. Kemudian, dilakukan pengelompokkan kedalaman tiap 1.000 kaki untuk melihat perubahan diagenesis mineral. Dari plot silang ini terlihat bahwa ada indikasi perubahan mineral dari smektit menjadi ilit seiring dengan bertambahnya kedalaman. Keberadaan tekanan luap pada sumur ini diduga diakibatkan juga oleh adanya diagenesis mineral lempung. Analisis kematangan batuan induk juga dilakukan untuk mengetahui apakah ada penyebab lain selain diagenesis mineral lempung. Dari Gambar 8 terlihat bahwa batuan induk telah memasuki jendela kematangan awal dimulai dari kedalaman 8.100 kaki di bawah permukaan laut. Maka dapat disimpulkan bahwa diagenesis mineral lempung dan kematangan batuan induk berkontribusi terhadap keberadaan tekanan luap pada sumur ini.

\subsubsection{Sumur ITB-3}

Berdasarkan plot silang pada Gambar 9, terlihat adanya perubahan mineral lempung dari smektit

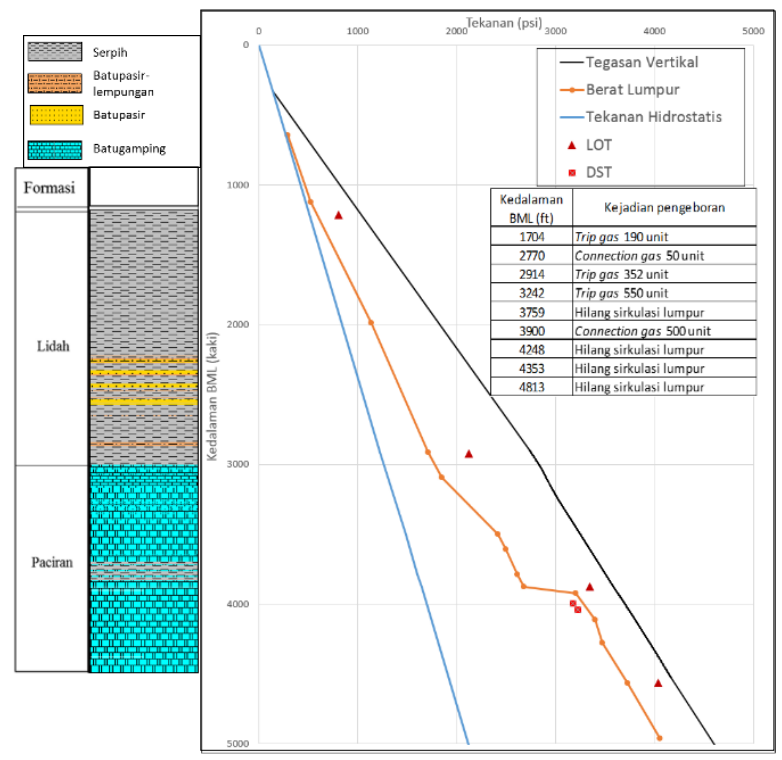

Gambar 6. Profil korelasi antara litologi, tekanan dan kedalaman pada Sumur ITB-4.

menjadi ilit seiring dengan bertambahnya kedalaman. Pada kedalaman 5.200-6.900 kaki di bawah permukaan laut, data plot silang masih berada pada garis mineral smektit. Kedalaman 6.900-7.900 kaki di bawah permukaan laut data plot silang berada pada daerah transisi dari garis smektit dan garis ilit. Kemudian pada kedalaman 7.900-9.653 kaki di bawah permukaan laut data plot silang telah berada pada garis ilit. Dengan demikian, dapat disimpulkan bahwa indikasi diagenesis mineral dari smektit menjadi ilit berkontribusi terhadap keberadaan tekanan luap pada Sumur ITB-3. Selain diagenesis mineral lempung, data kematangan batuan induk juga menjelaskan penyebab terjadinya tekanan luap pada sumur ini. Hasil analisis reflektansi vitrinit (Gambar 10) menunjukkan bahwa pada kedalaman pada 7.000 kaki di bawah permukaan laut nilai reflektansi vitrinit telah lebih besar dari 0,6. Artinya, batuan induk pada sumur ini telah matang mulai dari kedalaman $7.000 \mathrm{ft}$. Batuan induk yang telah matang ini juga berkontribusi penyebab adanya tekanan luap di sumur ini. Berdasarkan beberapa kondisi tersebut, dapat disimpulkan bahwa diagenesis mineral lempung dan kematangan hidrokarbon berkontribusi terhadap terjadinya tekanan luap pada Sumur ITB-3. 


\subsubsection{Sumur ITB-4}

Sumur ITB-4 tidak memiliki data log sonik pada interval serpih. Oleh karena itu, analisis plot silang untuk mengetahui adanya pengaruh diagenesis mineral lempung terhadap pembentukan tekanan luap tidak bisa dilakukan. Untuk mengetahui pengaruh kematangan hidrokarbon terhadap keberadaan tekanan luap pada sumur ini, dilakukan pemodelan kematangan berdasarkan data kematangan batuan induk dari sumur terdekat, yaitu Sumur ITB-2 (Gambar 11). Data reflektansi vitrinit Sumur ITB-2 digunakan sebagai validasi pemodelan kematangan, kemudian dengan parameter yang sama, pemodelan kematangan diaplikasikan pada Sumur ITB-4. Metoda ini digunakan karena pada Sumur ITB-4 tidak dilakukan analisis geokimia kematangan batuan induk. Hasil pemodelan kematangan batuan induk Sumur ITB-4 memperlihatkan bahwa reflektansi vitrinit hingga pada kedalaman akhir sumur hanya berada pada nilai 0,5 , hal ini mengindikasikan bahwa apabila terdapat batuan induk pada sumur ini, batuan induk tersebut belum matang dan tidak berperan dalam pembentukan tekanan luap.

Penyebab keberadaan tekanan luap dengan mekanisme nonpembebanan dapat dikesampingkan. Untuk mengetahui adanya pengaruh kegagalan kompaksi, dilakukan pemodelan sejarah pemendaman Sumur ITB-4 (Gambar 12). Kegagalan kompaksi yang berakibat adanya tekanan luap terjadi karena sedimentasi yang cepat sehingga fluida yang berada pada sedimen tidak sempat keluar. Besarnya laju sedimentasi ditabulasikan dalam Tabel 1. Terlihat bahwa laju pengendapan pada sumur ini sebesar $328 \mathrm{~m} / \mathrm{juta}$ tahun. Hasil penelitian Swarbrick dkk. (2002) menyatakan bahwa laju sedimentasi yang dapat menyebabkan tekanan luap sangat bervariasi, mulai dari $35 \mathrm{~m} / \mathrm{juta}$ tahun hingga $3.000 \mathrm{~m} / \mathrm{juta}$ tahun. Besarnya sedimentasi ini yang menjadi faktor seberapa kedalaman puncak tekanan luap, selain jenis litologi.

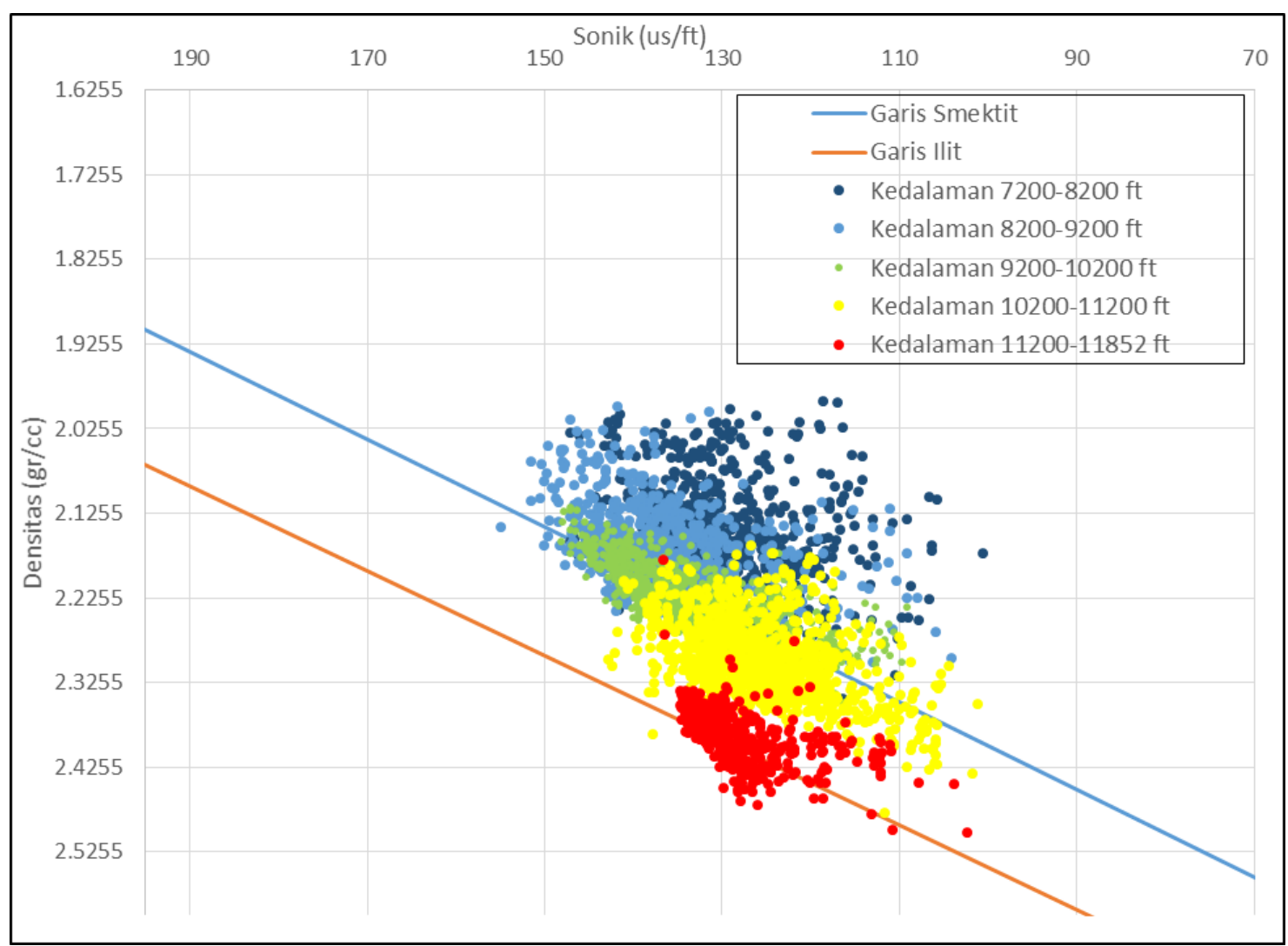

Gambar 7. Plot silang log densitas dan sonik serta hubungannya dengan diagenesis mineral lempung Sumur ITB-2. 


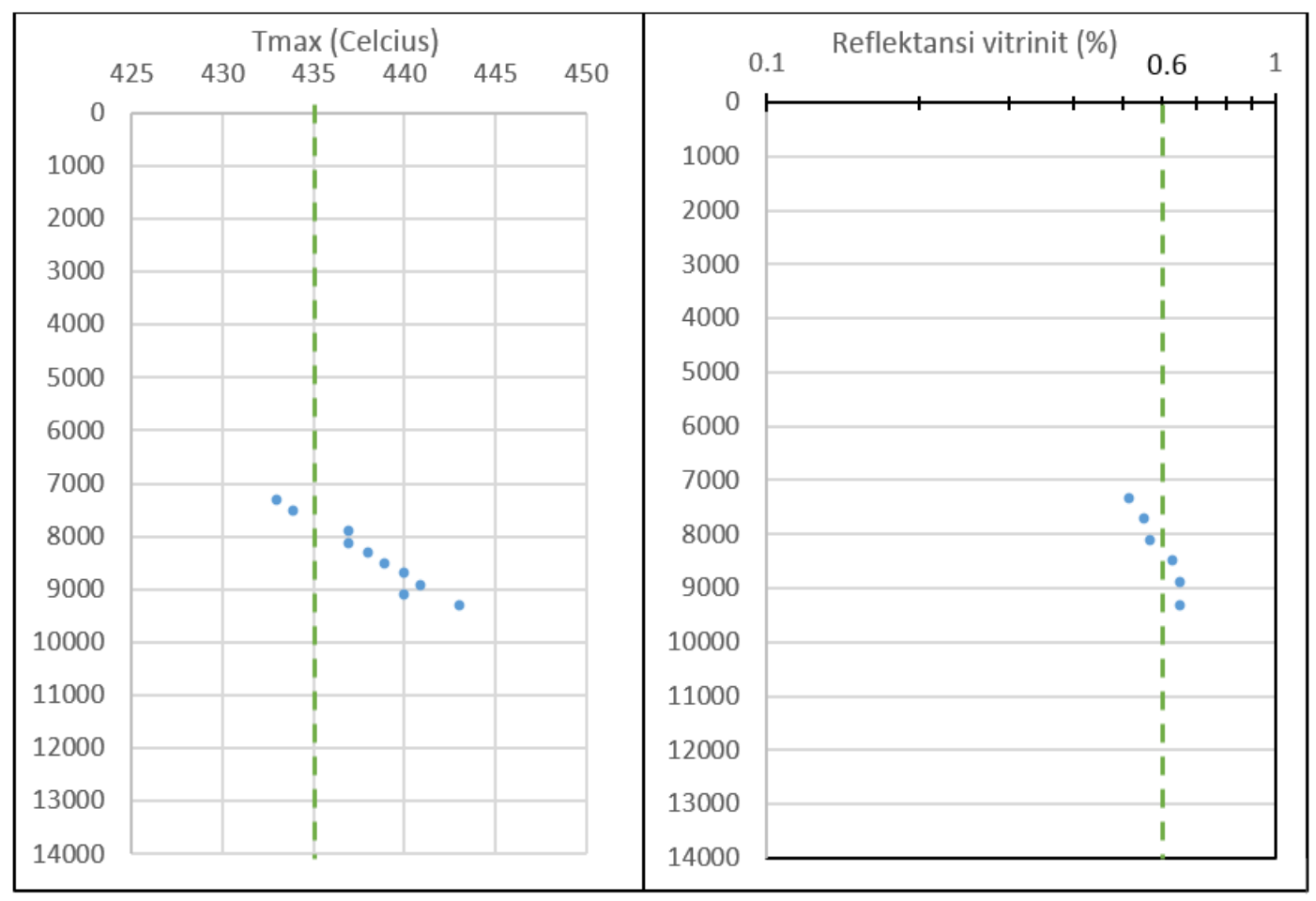

Gambar 8. Kematangan batuan induk sumur ITB-2.

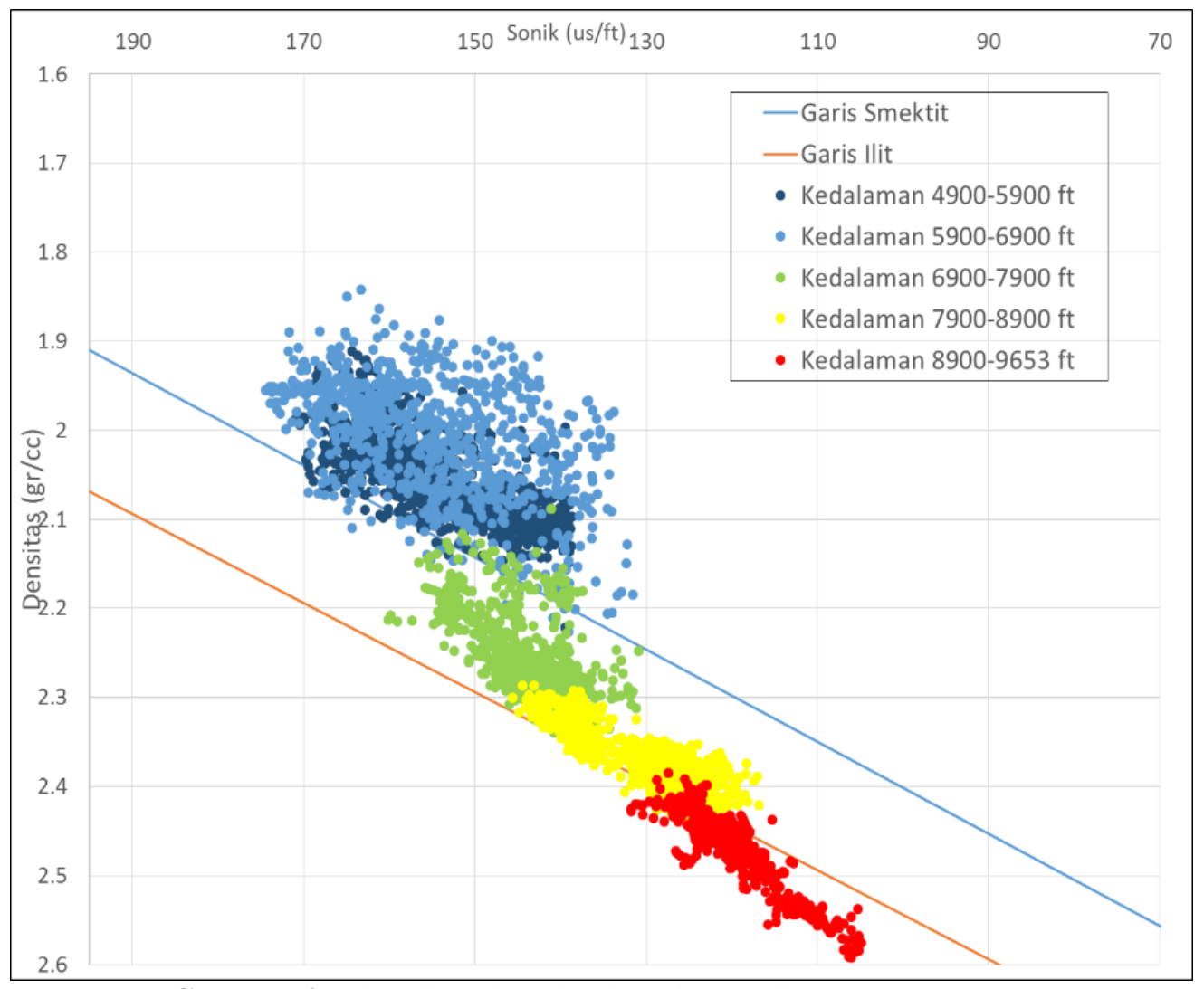

Gambar 9. Plot silang log densitas dan sonik Sumur ITB-3. 


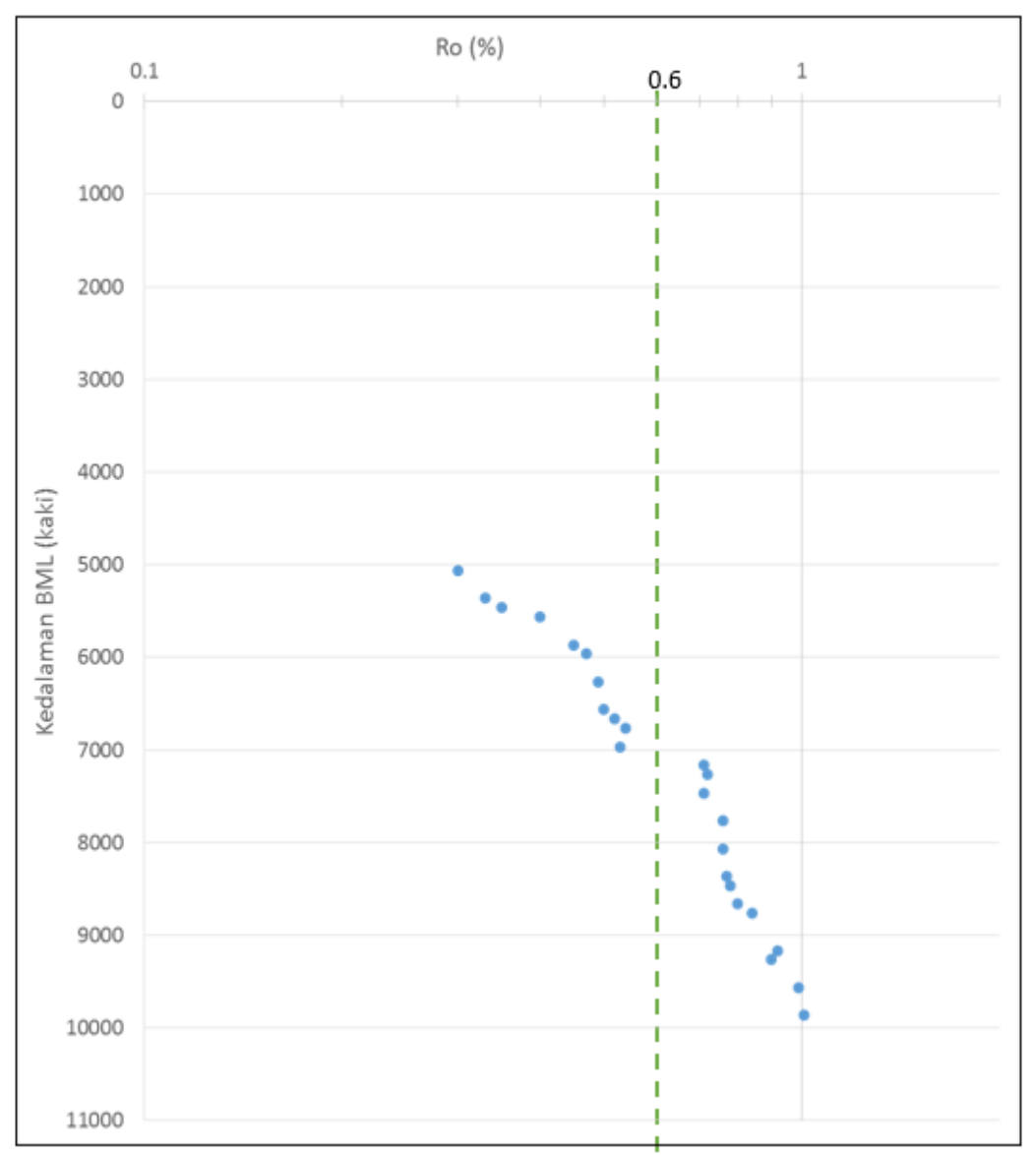

Gambar 10. Plot reflektansi vitrinit Sumur ITB-3.

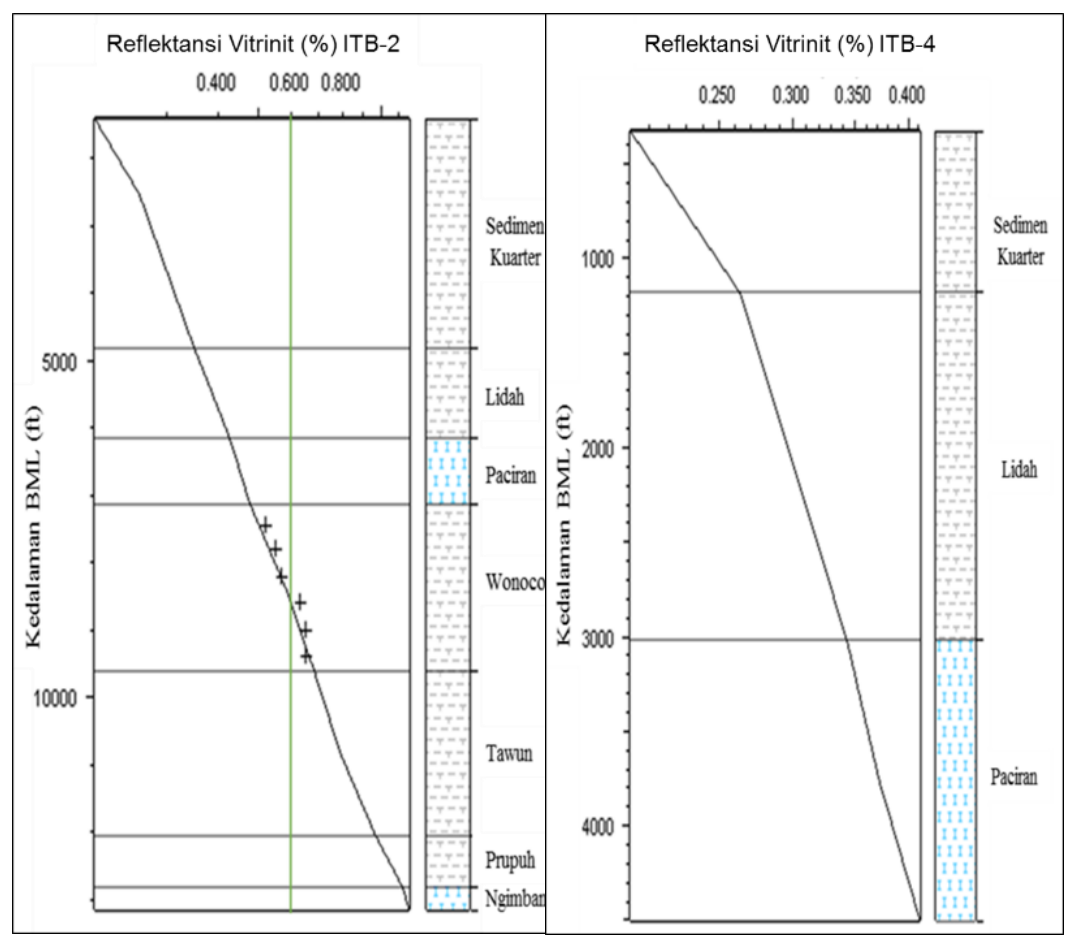

Gambar. 11. Pemodelan kematangan Sumur ITB-2 dan Sumur ITB-4. 


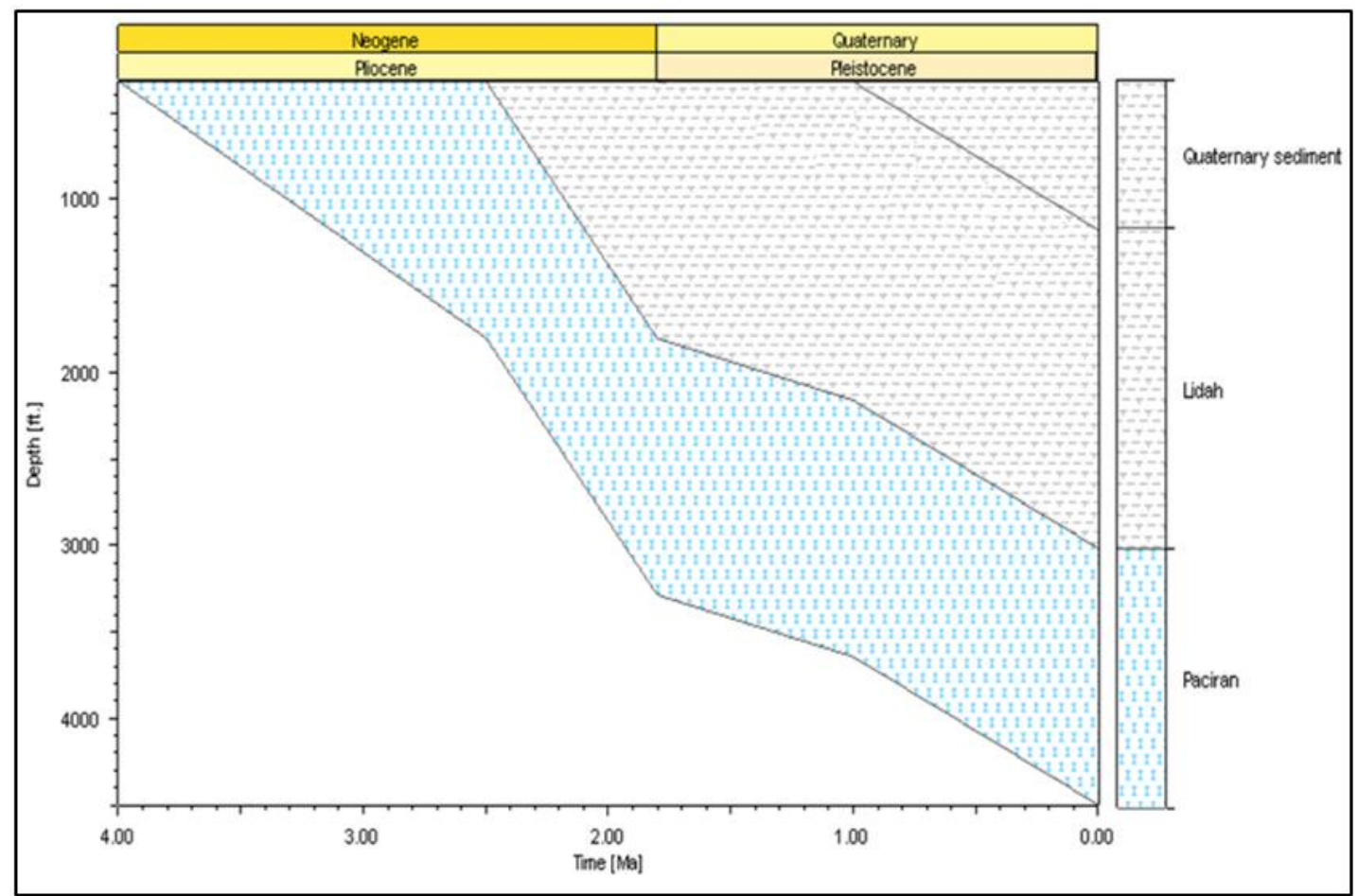

Gambar. 12. Sejarah pemendaman Sumur ITB-4.

Tabel 1. Tabulasi kecepatan sedimentasi Sumur ITB-4.

\begin{tabular}{|l|l|l|l|l|}
\hline Formasi & $\begin{array}{c}\text { Tebal } \\
(\mathrm{kaki})\end{array}$ & $\begin{array}{c}\text { Waktu } \\
\text { pengendapan (jt) }\end{array}$ & $\begin{array}{c}\text { Laju pengendapan } \\
(\mathrm{ft} / \mathrm{jt})\end{array}$ & \multicolumn{1}{|c|}{$\begin{array}{c}\text { Laju pengendapan } \\
(\mathrm{m} / \mathrm{jt})\end{array}$} \\
\hline Lidah & 2.694 & 2,5 & $1.077,6$ & 328,45248 \\
\hline Paciran & 1.482 & 1,5 & 988 & 301,1424 \\
\hline
\end{tabular}

\subsection{Estimasi tekanan pori}

Estimasi tekanan pori dilakukan menggunakan Metode Eaton (Gambar 13 dan Gambar 14). Metode ini diawali dengan membuat kurva porositas normal yang disebut juga sebagai tren kompaksi normal. Tren kompaksi normal dibutuhkan kemudian dipakai untuk menentukan seberapa besar penyimpangan log tali kawat dari tren kompaksi normal.

Hasil prediksi tekanan pori Metoda Eaton Sumur ITB-3 cukup berkorelasi dengan tekanan berdasarkan lumpur pengeboran. Prediksi tekanan pori Eaton pada sumur ini menggunakan pangkat 2,6 untuk log sonik (Gambar 13).

Dari estimasi tekanan pori Sumur ITB-4 terlihat bahwa kedalaman puncak tekanan luap berada pada 1600 kaki bawah permukaan laut. Pangkat Eaton yang digunakan sebesar 1,1 untuk log sonik cukup mendekati nilai tekanan berat lumpur (Gambar 14). 


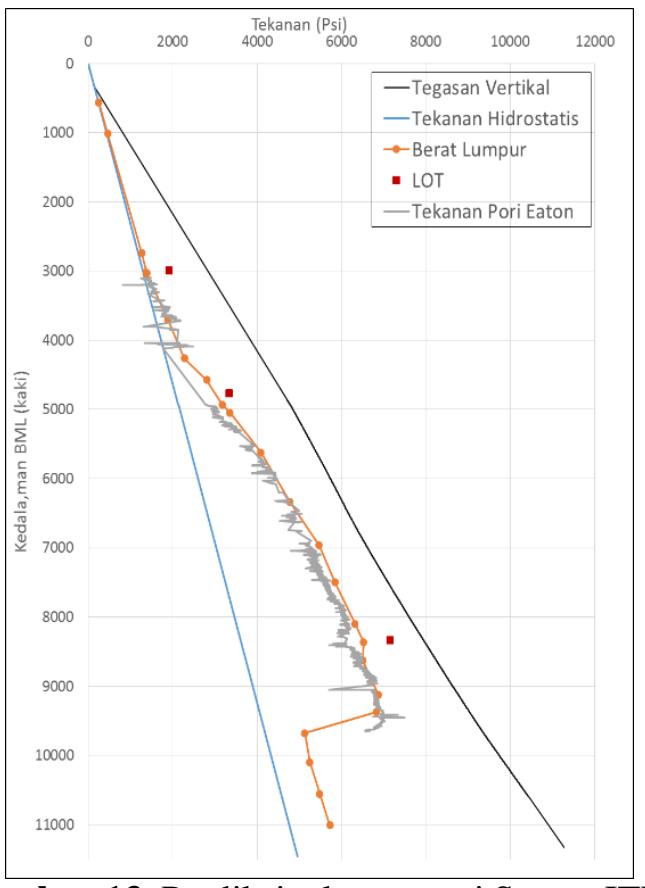

Gambar 13. Prediksi tekanan pori Sumur ITB-

\subsection{Diskusi}

Kondisi tekanan pori daerah penelitian ada yang berada pada kondisi hidrostatis dan ada yang berada pada kondisi tekanan luap. Dari Tabel 2 terlihat Sumur ITB-1 tidak mengalami tekanan luap, sedangkan pada Sumur ITB-2, ITB-3, dan ITB-4 mengalami tekanan luap. Selain itu, puncak tekanan luap tiap sumur memiliki kedalaman yang berbeda-beda.

Tekanan luap di daerah penelitian muncul di Sumur ITB-3 pada Formasi Wonocolo serta di Sumur ITB-4 dan Sumur ITB-2 pada Formasi Lidah (Gambar 15). Formasi Lidah di sumur tersebut tersusun atas serpih yang sangat tebal, sedangkan di Sumur ITB-3 masih terdapat sisipan-sisipan batupasir. Pengendapan serpih yang sangat tebal di Sumur ITB-3 terdapat pada Formasi Wonocolo. Hal ini menunjukkan bahwa puncak tekanan luap tidak sepenuhnya dikontrol oleh batas formasi melainkan oleh komposisi litologi.

Hal yang juga cukup menarik untuk diperhatikan adalah hubungan antara diagenesis mineral lempung dan kematangan batuan induk.

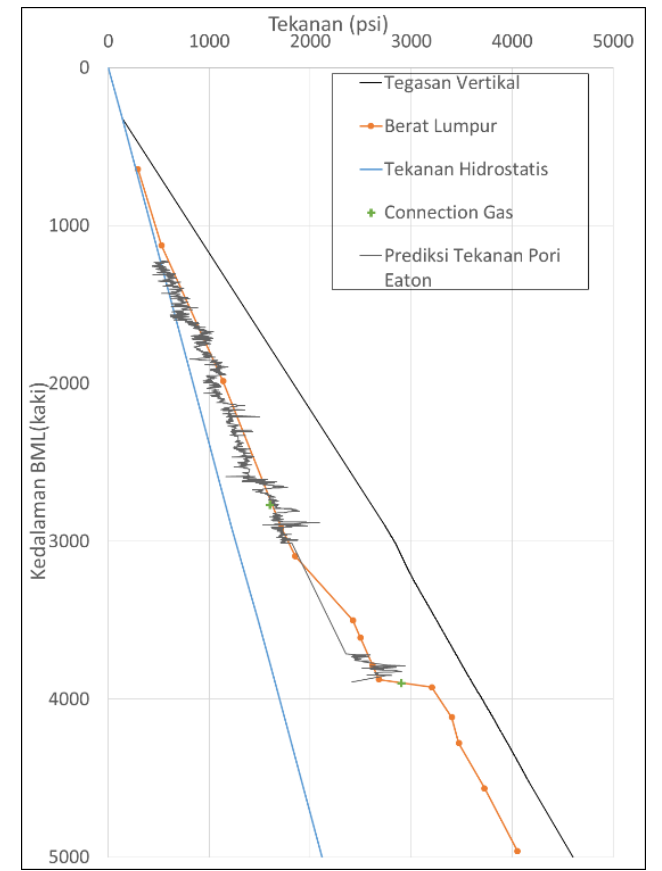

. Gambar 14. Prediksi tekanan pori Sumur ITB-4.

Penentuan titik kedalaman diagenesis mineral lempung pada Gambar 15 adalah berdasarkan plot silang log densitas dan log sonik dari Gambar 9 untuk Sumur ITB-3 dan Gambar 7 untuk Sumur ITB-2. Pada kedalaman tersebut, mineral smektit telah sepenuhnya bertransformasi menjadi mineral ilit karena data plot silang densitas-sonik telah berada pada garis ilit.

Dari Gambar 15 terlihat bahwa garis jendela kematangan hidrokarbon berada pada zona yang lebih dangkal dibandingkan dengan garis diagenesis mineral lempung. Hal ini dapat dijelaskan melalui Gambar 16 dan Gambar 17. Pada kedua gambar tersebut terlihat bahwa untuk tingkat kematangan batuan induk yang sama, batuan yang berumur lebih tua menghasilkan konsentrasi mineral ilit yang lebih tinggi. Meunier dan Velde (2004) menyimpulkan bahwa dalam hal transformasi mineral lempung, faktor waktu lebih berpengaruh dibandingkan faktor temperatur, sementara dalam hal tahapan kematangan batuan induk, faktor temperatur lebih berpengaruh dibandingkan dengan faktor waktu. 
Tabel 2. Rangkuman kondisi tekanan pori di daerah penelitian.

\begin{tabular}{|c|c|c|c|}
\hline Sumur & Kondisi tekanan pori & $\begin{array}{c}\text { Kedalaman puncak } \\
\text { tekanan luap (kaki) }\end{array}$ & $\begin{array}{c}\text { Formasi di puncak tekanan } \\
\text { luap (dominasi litologi) }\end{array}$ \\
\hline ITB-1 & Hidrostatik & - & - \\
\hline ITB-2 & Tekanan luap & $4.400-5.200$ & Lidah (serpih) \\
\hline ITB-4 & Tekanan luap & 1.600 & Lidah (serpih) \\
\hline ITB-3 & Tekanan luap & 5.100 & Wonocolo (serpih) \\
\hline
\end{tabular}

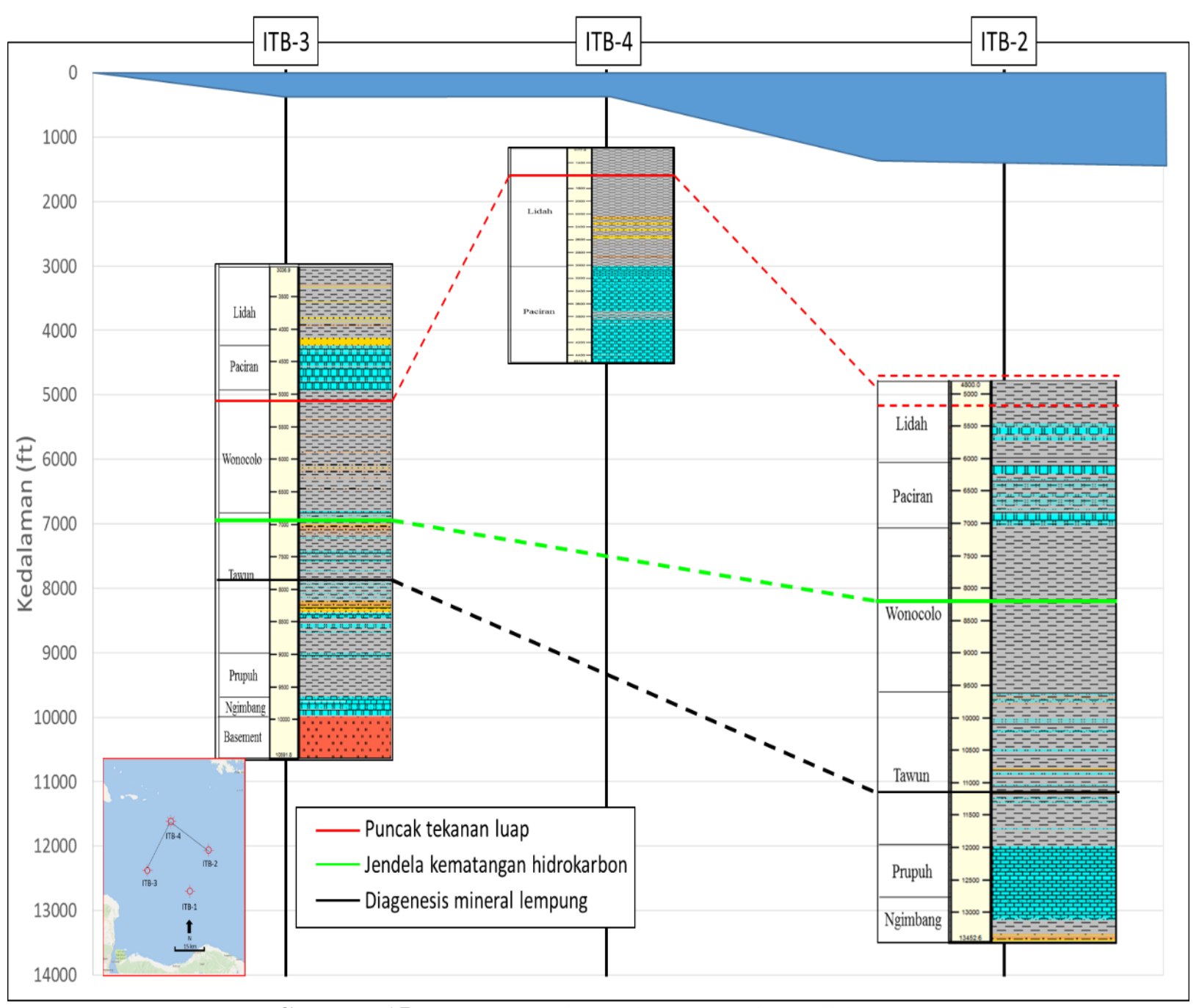

Gambar 15. Penampang barat-timur lokasi penelitian. 


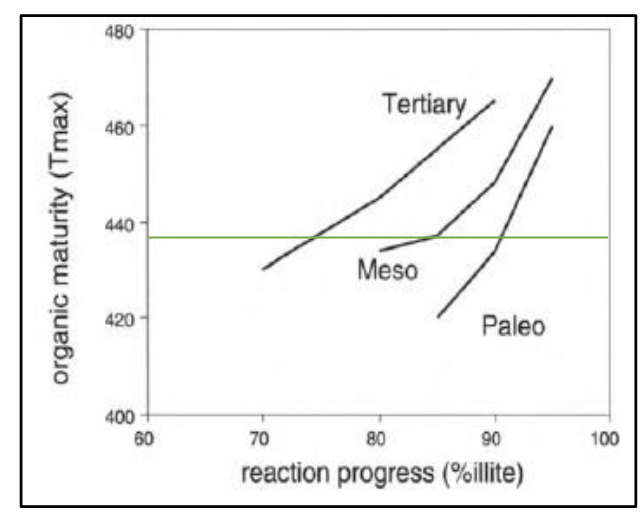

Gambar 16. Data kematangan organik dan konsentrasi mineral ilit/smektit yang dibedakan berdasarkan umur batuan. Data diambil dari penelitian Xinhau dkk. (1996) dalam Meunier dan Velde (2004).

Penampang skematik korelasi sumur daerah penelitian (Gambar 15) dapat membantu menggambarkan keadaan tekanan luap apabila dilakukan pengeboran sumur baru yang berlokasi dekat dengan daerah penelitian. Apabila pengeboran sumur baru dilakukan di lokasi yang berada di antara Sumur ITB-3 dan Sumur ITB-2, tekanan luap kemungkinan akan dijumpai pada kedalaman 4.800-5.200 kaki di bawah permukaan laut. Semakin ke utara dari lokasi ini, tekanan luap kemungkinan akan dijumpai pada kedalaman yang relatif lebih dangkal, mendekati kedalaman puncak tekanan luap yang dijumpai pada Sumur ITB-4, yaitu 1.600 kaki. Semakin mendekati Sumur ITB-1, kemungkinan tidak akan dijumpai tekanan luap. Hal ini tentu perlu dikonfirmasi juga dengan analisis dari penampang seismik agar pengetahuan mengenai keterdapatan dan kedalaman puncak tekanan luap dapat diketahui secara lebih baik.

\section{KESIMPULAN}

Berdasarkan analisis yang telah dilakukan, dapat disimpulkan bahwa tekanan luap dijumpai pada tiga sumur, yaitu sumur ITB-2, ITB-3, dan ITB-4. Sumur ITB-1 berada pada kondisi hidrostatik. Kedalaman puncak tekanan luap tiap sumur berbeda-beda dan lebih dikontrol oleh komposisi litologi. Keberadaan tekanan

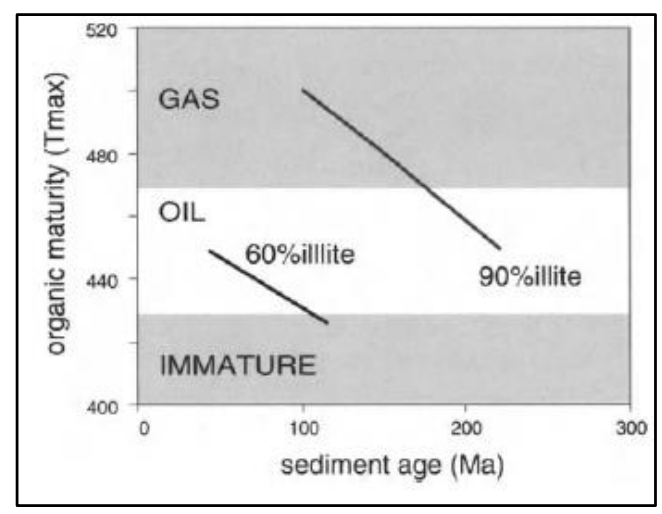

Gambar 17. Kematangan batuan induk dibandingkan dengan kandungan mineral ilit dan smektit. Data dari penelitian Velde dan Espitalie (1989) dalam Meunier dan Velde (2004).

luap diakibatkan oleh kegagalan kompaksi batuan, kematangan hidrokarbon, dan diagenesis mineral lempung. Prediksi tekanan pori berdasarkan Metoda Eaton menggunakan log sonik dapat menghasilkan estimasi tekanan pori yang cukup sesuai pada daerah penelitian dengan menggunakan pangkat eaton 1,1-2,6.

\section{DAFTAR PUSTAKA}

BP Migas dan LAPI ITB (2008): Cekungan Jawa Timur, Tektonik dan cekungan Indonesia, 29, 8-27.

Dutta, N.C. (2002): Deepwater geohazard prediction using prestack inversion of large offset $\mathrm{P}$-wave data and rock model. The Leading Edge, 21, 193-198.

Eaton, B. (1975): The equation for geopressure prediction from well $\operatorname{logs}$, SPE Fall Meeting of AIME, Dallas, Texas, 28 September-1 Oktober.

Heller, J., O'Connor, S., Emery, A., Hoskin, E., Lee, J., dan Ward, C. (2015): The effect of unconformities and subsequent loading on pore pressure profile, Proceeding of the 39th Annual Convention and Exhibition Indonesian Petroleum Association, Jakarta, Indonesia, Indonesia Petroleum Association, 1-15.

Manik, P. dan Soedaldjo, P.A. (1984): Prediction of abnormal pressure based on seismic data: a case study of 
exploratory well drilling in Pertamina UEP I and UEP II work areas, Proceeding of the 13th Annual Convention and Exhibition Indonesian Petroleum Association, Jakarta, Indonesia, Indonesia Petroleum Association, 461-505.

Ramdhan, A.M., dan Goulty N.R. (2011): Overpressure and mudrock compaction in the Lower Kutai Basin, Indonesia: a radical reappraisal, AAPG Bulletin, 10, 1725-1744.

Swarbrick, R.E. dan Osborne, M.J. (1998): Mechanism that generate abnormal pressure: an overview, 13-34 dalam Law, B. E., Ulmishek, G. F., dan Slavin, V. I., Eds, Abnormal Pressures in Hydrocarbon Environments, 264 p., AAPG Memoir 70, Tulsa-Amerika Serikat.

Tingay, M. (2015): The Lusi mud volcano disaster Indonesia: lessons for safe drilling and pore pressure prediction, AAPG Discover, 8, 9-10.

Meunier, A. dan Verde, B. (2004): Illite: origins, evolution and metamorphism, Springer, Heidelberg, 207-209. 